\title{
First Report on the Ethnopharmacological Uses of Medicinal Plants by Monpa Tribe from the Zemithang Region of Arunachal Pradesh, Eastern Himalayas, India
}

\author{
Tamalika Chakraborty ${ }^{1,2}$, Somidh Saha ${ }^{3,4,5, *}$ and Narendra S. Bisht ${ }^{3,6}$ \\ 1 Institute of Ethnobiology, School of Studies in Botany, Jiwaji University, Gwalior 474011, India; \\ tamalika.chakraborty@waldbau.uni-freiburg.de \\ 2 Chair of Site Classification and Vegetation Science, Institute of Forest Sciences, University of Freiburg, \\ Tennenbacherstr. 4, D-79106 Freiburg, Germany \\ 3 Resource Survey and Management Division, Forest Research Institute, PO New Forest, Dehra Dun 248006, \\ India; bishtnsifs@yahoo.com \\ 4 Chair of Silviculture, Institute of Forest Sciences, University of Freiburg, Tennenbacherstr. 4, \\ D-79106 Freiburg im Breisgau, Germany \\ 5 Institute for Technology Assessment and Systems Analysis (ITAS), Karlsruhe Institute of Technology (KIT), \\ Karlstr. 11, D-76133 Karlsruhe, Germany \\ 6 Directorate of Extension, Indian Council of Forestry Research and Education, PO New Forest, \\ Dehra Dun 248006, India \\ * Correspondence: somidh.saha@waldbau.uni-freiburg.de or somidhs@gmail.com; \\ Tel.: +49-761-203-8627; Fax: +49-761-203-3781
}

Academic Editor: Milan S. Stankovic

Received: 28 November 2016; Accepted: 24 February 2017; Published: 2 March 2017

\begin{abstract}
The Himalayas are well known for high diversity and ethnobotanical uses of the region's medicinal plants. However, not all areas of the Himalayan regions are well studied. Studies on ethnobotanical uses of plants from the Eastern Himalayas are still lacking for many tribes. Past studies have primarily focused on listing plants' vernacular names and their traditional medicinal uses. However, studies on traditional ethnopharmacological practices on medicine preparation by mixing multiple plant products of different species has not yet been reported in published literature from the state of Arunachal Pradesh, India, Eastern Himalayas. In this study, we are reporting for the first time the ethnopharmacological uses of 24 medicines and their procedures of preparation, as well as listing 53 plant species used for these medicines by the Monpa tribe. Such documentations are done first time in Arunachal Pradesh region of India as per our knowledge. Our research emphasizes the urgent need to document traditional medicine preparation procedures from local healers before traditional knowledge of tribal people living in remote locations are forgotten in a rapidly transforming country like India.
\end{abstract}

Keywords: medicinal plants; traditional knowledge; Eastern Himalayas; mountain plants; ethnobotany; ethnopharmacology; bioprospecting

\section{Introduction}

The Himalayas are rich in diversity of medicinal plant species [1]. The culture of traditional healing of diseases using these plants is still prevalent among aboriginal mountain communities in the Himalayas. Arunachal Pradesh (approximately $84,000 \mathrm{~km}^{2}$ in size), a state belonging to the Republic of India, is situated in the Eastern Himalayas. The entire state is declared as a "biodiversity hotspot" with 5000 endemic flowering plant species as well as very high faunal diversity [1,2]. Also, this state 
is the home to 28 major tribes and 110 sub-tribes and is considered to be one of the most splendidly variegated and multilingual tribal areas of the world [3]. The traditional wisdom of healing among mountain tribal communities is orally transferred from one generation to the next generation through traditional healers, spiritual gurus, and elderly or sometimes ordinary people. This traditional wisdom, if not properly documented, can be lost by rapid modernization and religious reformation among mountain communities in Arunachal Pradesh where traditional customary practices are often regarded as a symbol of "backwardness" and "unscientific" by the educated and younger generations. Nevertheless, plant-based traditional wisdom inherited and carried forward to generation after generation in traditional communities has become a recognized tool in the search for new sources of drugs and pharmaceuticals in modern medicine [4]. Therefore, field based ethnobotanical and ethnopharmacological surveys to list medicinal plants and their uses are still relevant and worth the effort in order to bring out new clues for the development of drugs to treat human diseases [5].

Before coming to our research objectives, we would like to briefly mention the state of the art of ethnopharmacological research in the Himalayas. There are plenty of research works on the listing of the traditional uses of medicinal plants from the Himalayas. A search with the terms "medicinal plants * Himalayas" yielded 163 peer-reviewed articles listed in ISI Web of Knowledge on 20 February 2017. However, out of those 163 articles, 19 articles were found from the Eastern Himalayas and only two were on the Monpa tribe (please see Materials and Methods section for a detailed sociocultural description of the Monpa tribe). Haridasan et al., in the seminal works produced in 1998 and 1990, comprehensively listed medicinal and edible plants of the Monpa tribe and other tribes of Arunachal Pradesh [2]. Recently, Namsa et al. (2011) listed 50 plant species and recorded their ethnobotanical uses among people of the Monpa tribe at the southern range of their habitation (i.e., Kalaktang circle of West Kameng district of Arunachal Pradesh) [6]. These two publications provided general descriptions of the plants, traditional uses of the plants to cure certain diseases, and traditional ways of consumption of these plants or plant parts (e.g., pills, syrups, decoctions, etc.). Nevertheless, no ethnopharmacological studies have yet reported how, and in what proportion, multiple plant parts from different species can be used to prepare specific ethnomedicines for healing of diseases among the Monpa tribes or any other tribes of the Eastern Himalayas as per our literature research as of 20 February 2017. In addition, the traditional knowledges of the people of the Monpa tribe residing at their northern habitation range (i.e., Zemithang circle of Tawang district of Arunachal Pradesh) are still not adequately documented due to the remoteness of the location.

Documentations of traditional ethnopharmacological know-hows are necessary for the preservation of traditional knowledges of Himalayan tribal communities. Such documentations could create interest among professional pharmacologists for the search of new medicines and motivate ethnologists to study high cultural diversity of the Eastern Himalayas of India. Those were the main motivations to carry out this research. This study aims to document traditional ethnopharmacological know-hows of medicinal drug making among Monpa people in the Zemithang region of the state of Arunachal Pradesh.

\section{Results}

Our study was a notable departure from the previous studies from the area that mostly documented and described the use of plant parts in individual plant species. We documented and described 24 ethnomedicines prepared by traditional healers based on 53 species (Table 1). The medicines were comprised of 53 plant species of medicinal plants belonging to 21 families (Table 2). These traditional medicines were most commonly used to heal a wide range of diseases such as arthritis, rheumatic pain, malaria, cough and cold, dysentery, etc. In addition, we recorded descriptions of medicines for the treatment of diseases such as epilepsy (Pambrey), herpes (Bukbukpa-khaksa-chandongbra), and oedema (Darshek sheng nye putpoo) that have rarely been reported in past studies. Our main result is presented in Table 1 which provides a list of ethnomedicines and their preparations by traditional ethnopharmacological techniques. 
Table 1. List of 24 ethnomedicines used by the Zemithang Monpa people and the associated medicinal plants documented in this study.

\begin{tabular}{|c|c|c|c|c|c|c|}
\hline Number & $\begin{array}{l}\text { Name of the } \\
\text { Ethnomedicines } \\
\text { (in Monpa Tribal } \\
\text { Language of } \\
\text { Zemithang Dialect) }\end{array}$ & $\begin{array}{c}\text { Type of } \\
\text { Medicines }\end{array}$ & $\begin{array}{l}\text { Name of Medicinal Plants Used } \\
\text { for Ethnomedicines }\end{array}$ & $\begin{array}{l}\text { Proportion of Used Plant Parts (Bray in } \\
\text { local language is a Buddhist prayer bowl. } \\
\text { It could be made of gold, silver, brass, } \\
\text { copper, stone, or wood and is often used } \\
\text { for religious offerings. } 1 \text { bray can contain } \\
\text { approximately } 900 \mathrm{~g} \text { of grain). }\end{array}$ & Mode of Preparations & Medicinal Uses \\
\hline 1 & Arkadamasisi & paste & Crawfurdia speciosa Wall. & $\begin{array}{c}1 / 4 \text { bray of dried root }+1 / 8 \text { bray of } \\
\text { dried flower }\end{array}$ & $\begin{array}{l}\text { dried roots and flower crushed } \\
\text { together to prepare powder and then } \\
\text { mixed with water to prepare paste }\end{array}$ & $\begin{array}{l}\text { paste is applied externally } \\
\text { for healing wounds }\end{array}$ \\
\hline 2 & Baribama & decoction & Aristolochia griffithii Hook.f. & $1 / 8$ bray of raw washed roots & $\begin{array}{l}\text { roots are boiled with water to prepare } \\
\text { a decoction }\end{array}$ & $\begin{array}{l}\text { decoction is taken as blood } \\
\text { purifier and purgative }\end{array}$ \\
\hline 3 & Blenga & pills & Hedychium spicatum Buch.-Ham. & 1 bray of washed raw roots & $\begin{array}{l}\text { raw roots are crushed and small round } \\
\text { pills are prepared and sun dried }\end{array}$ & $\begin{array}{l}\text { pills are taken orally for } \\
\text { treatment of dysentery, } \\
\text { chest pain, cough and cold }\end{array}$ \\
\hline 4 & Bomdeng & paste & $\begin{array}{l}\text { Cirsium falconeri Hook.f., Cirsium } \\
\text { verutum D. Don and } \\
\text { Onopordum acanthium L. }\end{array}$ & $\begin{array}{l}1 / 2 \text { bray of washed raw root of } C \text {. falconeri }+ \\
1 / 2 \text { bray of washed raw root of } C \text {. verutum }+ \\
3 / 4 \text { bray of washed raw root of } O \text {. acanthium }\end{array}$ & $\begin{array}{l}\text { raw roots are mixed together and } \\
\text { crushed to prepare paste }\end{array}$ & $\begin{array}{l}\text { paste is applied externally } \\
\text { to treat arthritis }\end{array}$ \\
\hline 5 & Bragen & syrup & $\begin{array}{l}\text { Bergenia stracheyi } \\
\text { Hook.f. \& Thorns. }\end{array}$ & 1 bray of washed fresh leaves & $\begin{array}{l}\text { clear fresh leaves are crushed to } \\
\text { prepare paste and mixed with } 1 / 4 \text { bray } \\
\text { local millets wine to prepare syrup }\end{array}$ & $\begin{array}{l}\text { syrup is taken for treating } \\
\text { rheumatic pains }\end{array}$ \\
\hline 6 & $\begin{array}{l}\text { Bukbukpa-khaksa- } \\
\text { chandongbra }\end{array}$ & paste & $\begin{array}{l}\text { Campanula latifolia Linn., } \\
\text { Codonopsis clematidea Schrenk. } \\
\text { and Codonopsis viridis Wall. }\end{array}$ & $\begin{array}{l}1 / 2 \text { bray of washed fresh leaves and } 1 / 4 \\
\text { bray of fresh flowers of each species }+1 / 4 \\
\text { bray of conch powder }+1 / 4 \text { bray of water }\end{array}$ & $\begin{array}{l}\text { leaves and flowers are crushed } \\
\text { together and mixed with conch } \\
\text { powder and water to prepare paste }\end{array}$ & $\begin{array}{l}\text { paste is applied externally } \\
\text { to treat herpes }\end{array}$ \\
\hline 7 & $\begin{array}{l}\text { Chandoo-konghlin- } \\
\text { bhor }\end{array}$ & powder & $\begin{array}{l}\text { Aconitum ferox Wall. ex Ser., } \\
\text { Aconitum heterophyllum Wall. ex } \\
\text { Royle, Aconitum hookeri Stapf., } \\
\text { Geranium polyanthes Edgeworth } \\
\text { \& J. D. Hooker, Geranium } \\
\text { wallichianum D. Don and } \\
\text { Picrorhiza kurrooa Royle ex Benth. }\end{array}$ & $\begin{array}{l}1 \text { small dried root from each plants of } A \text {. } \\
\text { ferox, A. heterophyllum and A. hookeri (total } 5 \\
\mathrm{~g} \text { mixture of three plants) }+3 \text { bray of dried } \\
\text { root of G. polyanthes and G. wallichianum }+1 \\
\text { bray of dried root P. kurrooa }\end{array}$ & $\begin{array}{l}\text { all ingredients are mixed together and } \\
\text { crushed to prepare a powder }\end{array}$ & $\begin{array}{l}\text { powder is taken orally to } \\
\text { overcome poisoning effects }\end{array}$ \\
\hline 8 & Chhalachhusar & syrup & $\begin{array}{l}\text { Meconopsis grandis Prain and } \\
\text { Meconopsis paniculata D. Don }\end{array}$ & $\begin{array}{l}1 / 2 \text { bray of dry leaves from each plant }+1 / 2 \\
\text { bray of dy flowers from each plant }\end{array}$ & $\begin{array}{l}\text { dried leaves and flowers are mixed } \\
\text { together and crushed to prepare } \\
\text { powder, and a small amount of } \\
\text { powder }(5 \mathrm{~g}) \text { is mixed with } 1 \text { bray of } \\
\text { water to prepare a syrup }\end{array}$ & $\begin{array}{l}\text { syrup is taken to } \\
\text { treat sexually } \\
\text { transmitted diseases }\end{array}$ \\
\hline
\end{tabular}


Table 1. Cont.

\begin{tabular}{|c|c|c|c|c|c|c|}
\hline Number & $\begin{array}{l}\text { Name of the } \\
\text { Ethnomedicines } \\
\text { (in Monpa Tribal } \\
\text { Language of } \\
\text { Zemithang Dialect) }\end{array}$ & $\begin{array}{l}\text { Type of } \\
\text { Medicines }\end{array}$ & $\begin{array}{l}\text { Name of Medicinal Plants Used } \\
\text { for Ethnomedicines }\end{array}$ & $\begin{array}{l}\text { Proportion of Used Plant Parts (Bray in } \\
\text { local language is a Buddhist prayer bowl. } \\
\text { It could be made of gold, silver, brass, } \\
\text { copper, stone, or wood and is often used } \\
\text { for religious offerings. } 1 \text { bray can contain } \\
\text { approximately } 900 \mathrm{~g} \text { of grain). }\end{array}$ & Mode of Preparations & Medicinal Uses \\
\hline 9 & $\begin{array}{l}\text { Chhurchu } \\
\text { doho keusheng }\end{array}$ & pills & $\begin{array}{l}\text { Rheum australe D. Don, } \\
\text { Rheum nobile Hook.f. \& Thoms. } \\
\text { and Bistorta affinis D. Don }\end{array}$ & $\begin{array}{l}1 / 2 \text { bray of fresh roots from each species }+ \\
1 / 4 \text { bray of dried flowers from each species }\end{array}$ & $\begin{array}{l}\text { fresh roots and dried flowers are } \\
\text { crushed together to make a paste, then } \\
\text { small round pills are prepared and } \\
\text { sun dried }\end{array}$ & $\begin{array}{l}\text { pills are taken orally to } \\
\text { overcome poisoning effects }\end{array}$ \\
\hline 10 & Comrep & syrup & $\begin{array}{l}\text { Rubus ellipticus Smith and } \\
\text { Rubus paniculatus Smith }\end{array}$ & $1 / 2$ bray of fresh ripe fruits from each plant & $\begin{array}{l}\text { roots are mixed together and crushed to } \\
\text { prepare a thick syrup }\end{array}$ & $\begin{array}{l}\text { syrup is used for treatment } \\
\text { of cold and cough }\end{array}$ \\
\hline 11 & $\begin{array}{l}\text { Darshek sheng } \\
\text { nye putpoo }\end{array}$ & decoction & $\begin{array}{l}\text { Pieris formosa (Wallich) D. Don; } \\
\text { Vaccinium nummularia } \\
\text { Hook.f. \& Thoms. }\end{array}$ & $\begin{array}{c}1 / 4 \text { bray of fruits of } P \text {. formosa }+1 / 4 \text { bray of } \\
\text { fruits of } V \text {. numularia }+1 / 2 \text { bray of fresh } \\
\text { roots of } P \text {. formosa }+1 / 2 \text { bray of fresh roots } \\
\text { of } V \text {. numularia }\end{array}$ & $\begin{array}{l}\text { mixture of all fresh fruits and roots } \\
\text { along with water is boiled to prepare } \\
\text { a decoction }\end{array}$ & $\begin{array}{l}\text { decoction is taken to } \\
\text { cure oedema }\end{array}$ \\
\hline 12 & Dhamrep & paste & $\begin{array}{l}\text { Fragaria nubicola Lindl., Geum } \\
\text { elatum Wall. and Potentilla } \\
\text { peduncularis D. Don. }\end{array}$ & $\begin{array}{c}1 / 2 \text { bray of } F . \text { nubicola fresh fruits }+1 / 8 \text { bray } \\
\text { of dried roots of G. elatum }+1 / 4 \text { bray of } \\
\text { leaves of P. peduncularis }\end{array}$ & $\begin{array}{l}\text { fresh fruits, leaves, and dried roots are } \\
\text { crushed together to prepare a paste }\end{array}$ & $\begin{array}{l}\text { paste is taken orally to treat } \\
\text { cold, cough, and fever }\end{array}$ \\
\hline 13 & Gin sheng & powder & Panax pseudoginseng Wall. & $1 / 4$ bray of dried rhizomes & $\begin{array}{l}\text { dried rhizomes are crushed to prepare } \\
\text { powder, which is taken with water }\end{array}$ & $\begin{array}{c}\text { used for treating } \\
\text { depression and fatigue }\end{array}$ \\
\hline 14 & Karpo Chiito & paste & Iris clarkei Baker & $\begin{array}{c}1 / 4 \text { bray of dried flower, leaves, stem, } \\
\text { and root }\end{array}$ & $\begin{array}{l}\text { dried flowers, leaves, stem parts, } \\
\text { and roots are crushed together to } \\
\text { prepare powder and mixed with local } \\
\text { millets wine to prepare paste }\end{array}$ & $\begin{array}{l}\text { paste is used externally to } \\
\text { treat muscle pain }\end{array}$ \\
\hline 15 & Lowa bur & pills & $\begin{array}{l}\text { Lomatogonium carinthiacum } \\
\text { (Wulfen) Rchb. }\end{array}$ & $1 / 4$ bray of dried roots & $\begin{array}{l}\text { dried roots are crushed and small round } \\
\text { pills are prepared and sun dried }\end{array}$ & $\begin{array}{l}\text { pills are taken orally to } \\
\text { treat cold, cough, and fever }\end{array}$ \\
\hline 16 & Maraptang & pills & Houttuynia cordata Thunb. & $1 / 4$ bray of dried roots & $\begin{array}{l}\text { dried roots are crushed and small round } \\
\text { pills are prepared and sun dried }\end{array}$ & $\begin{array}{l}\text { pills are taken orally for } \\
\text { treatment of piles }\end{array}$ \\
\hline 17 & Nyasheng jormu & paste and pills & Viscum articulatum Burm. f. & $\begin{array}{l}1 / 4 \text { bray of fresh roots }+1 / 4 \text { bray of fresh } \\
\text { leaves }+1 / 4 \text { bray of fresh stems }\end{array}$ & $\begin{array}{l}\text { fresh roots, leaves, and parts of stem are } \\
\text { crushed together to prepare paste; } \\
\text { sometimes paste is used to prepare } \\
\text { small round pills and sun dried }\end{array}$ & $\begin{array}{l}\text { paste is used to join broken } \\
\text { bones, treating pain from } \\
\text { swelling of nerves and } \\
\text { healing wounds; pills are } \\
\text { used for treatment of } \\
\text { infertility among women }\end{array}$ \\
\hline
\end{tabular}


Table 1. Cont.

\begin{tabular}{|c|c|c|c|c|c|c|}
\hline Number & $\begin{array}{l}\text { Name of the } \\
\text { Ethnomedicines } \\
\text { (in Monpa Tribal } \\
\text { Language of } \\
\text { Zemithang Dialect) }\end{array}$ & $\begin{array}{c}\text { Type of } \\
\text { Medicines }\end{array}$ & $\begin{array}{l}\text { Name of Medicinal Plants } \\
\text { Used for Ethnomedicines }\end{array}$ & $\begin{array}{c}\text { Proportion of Used Plant Parts (Bray in local } \\
\text { language is a Buddhist prayer bowl. It could } \\
\text { be made of gold, silver, brass, copper, stone, } \\
\text { or wood and is often used for religious } \\
\text { offerings. } 1 \text { bray can contain approximately } \\
900 \mathrm{~g} \text { of grain). }\end{array}$ & Mode of Preparations & Medicinal Uses \\
\hline 18 & Pambrey & mixture & $\begin{array}{l}\text { Anaphalis monocephala DC., } \\
\text { Anaphalis triplinervis Sims., } \\
\text { Gnaphalium hypoleucum DC., } \\
\text { Leontopodium himalayanam DC., } \\
\text { Leontopodium jacotianum Beauv., } \\
\text { Tanacetum tibeticum Hook.f. } \\
\text { and Tanacetum gracile } \\
\text { Hook.f. \& Thoms. }\end{array}$ & $1 / 2$ bray of flowers from each of the plants & $\begin{array}{l}\text { flowers are kept in a dark place for } \\
\text { two days after plucking and then } \\
\text { mixed together }\end{array}$ & $\begin{array}{l}\text { used to treat epilepsy, } \\
\text { mildly warm mixtures are } \\
\text { applied on the bare head of } \\
\text { the patient (two times } \\
\text { a day) consecutively for } \\
15 \text { to } 20 \text { days }\end{array}$ \\
\hline 19 & Pangen & pills & $\begin{array}{l}\text { Gentiana depressa D. Don, } \\
\text { Gentiana ornata Wallich ex G. } \\
\text { Don, Gentiana phyllocalyx C. B. } \\
\text { Clarke and Gentiana tubiflora } \\
\text { Wallich ex G. Don. }\end{array}$ & $1 / 4$ bray of dried roots from each of the plants & $\begin{array}{l}\text { dried roots are crushed and then } \\
\text { mixed with } 1 / 4 \text { bray of local millet } \\
\text { wine and } 1 / 2 \text { bray of water and small } \\
\text { round pills are prepared and sun dried }\end{array}$ & $\begin{array}{l}\text { pills are used to treat } \\
\text { cough, cold, and headache }\end{array}$ \\
\hline 20 & Rah-nya & decoction & $\begin{array}{c}\text { Smilacina purpurea } \\
\text { S. oleracea and } \\
\text { Polygonatum multiflorum Allem. }\end{array}$ & $1 / 4$ bray of fresh roots from each of the plants & $\begin{array}{l}\text { roots are boiled with water to prepare } \\
\text { a decoction }\end{array}$ & $\begin{array}{l}\text { is used for the } \\
\text { treatment of malaria }\end{array}$ \\
\hline 21 & $\begin{array}{l}\text { Rambhoo } \\
\text { tsarphakur }\end{array}$ & paste & $\begin{array}{l}\text { Morina longifolia Wall., } \\
\text { Pterocephalus hookeri } \\
\text { (C. B. Clarke) Hock. }\end{array}$ & $\begin{array}{c}1 / 4 \text { bray of dried flowers, } 1 / 2 \text { bray of fresh } \\
\text { roots, } 1 / 4 \text { bray of fresh fruits of } M \text {. longifolia }+ \\
1 / 8 \text { bray of dried flower, } 1 / 2 \text { bray of fresh roots, } \\
1 / 2 \text { bray of fresh fruits of } P \text {. hookeri }\end{array}$ & $\begin{array}{l}\text { flowers, roots, and fruits of both plants } \\
\text { are mixed together and crushed to } \\
\text { prepare paste }\end{array}$ & $\begin{array}{l}\text { paste is applied for healing } \\
\text { chest pain }\end{array}$ \\
\hline 22 & Trahm-Sheng & paste & Corydalis cashmeriana Royle. & $\begin{array}{l}1 / 4 \text { bray of fresh leaves }+1 / 4 \text { bray of } \\
\text { fresh flower }\end{array}$ & $\begin{array}{l}\text { fresh leaves and flowers are crushed to } \\
\text { prepare paste }\end{array}$ & $\begin{array}{l}\text { paste is applied for } \\
\text { healing wounds }\end{array}$ \\
\hline 23 & Wang La & powder & $\begin{array}{c}\text { Swertia chirayita } \\
\text { (Roxb. ex Flem.) Karst. and } \\
\text { Swertia hookeri C. B. Clarke }\end{array}$ & $1 / 2$ bray of dried whole plants & $\begin{array}{l}\text { dried whole plants are crushed to } \\
\text { prepare powder, which is taken } \\
\text { with water }\end{array}$ & $\begin{array}{l}\text { powder is used to treat } \\
\text { malaria, and is also used as } \\
\text { a purgative and laxative }\end{array}$ \\
\hline 24 & Whan & pills & Lilium nepalense D. Don & $1 / 2$ bray of dried roots & $\begin{array}{l}\text { dried roots are crushed and mixed } \\
\text { with water to prepare small round } \\
\text { pills which are then sun dried }\end{array}$ & $\begin{array}{l}\text { pills are used for treating } \\
\text { gastritis and stomachic }\end{array}$ \\
\hline
\end{tabular}


Table 2. List of recorded plants used in Ethnomedicine.

\begin{tabular}{|c|c|c|c|}
\hline Serial Number & Botanical Name & Family & Type \\
\hline 1 & Aconitum ferox Wall. ex Ser. & Ranunculaceae & herb \\
\hline 2 & Aconitum heterophyllum Wall. ex Royle & Ranunculaceae & herb \\
\hline 3 & Aconitum hookeri Stapf. & Ranunculaceae & herb \\
\hline 4 & Anaphalis monocephala DC. & Compositae & herb \\
\hline 5 & Anaphalis triplinervis Sims. & Compositae & herb \\
\hline 6 & Aristolochia griffithii Hook.f. & Aristolochiaceae & vine \\
\hline 7 & Bergenia stracheyi Hook.f. \& Thorns. & Saxifragaceae & herb \\
\hline 8 & Bistorta affinis D. Don & Polygonaceae & herb \\
\hline 9 & Campanula latifolia Linn. & Campanulaceae & herb \\
\hline 10 & Cirsium falconeri Hook. f. & Asteraceae & herb \\
\hline 11 & Cirsium verutum D. Don & Asteraceae & herb \\
\hline 12 & Codonopsis clematidea Schrenk. & Campanulaceae & herb \\
\hline 13 & Codonopsis viridis Wall. & Campanulaceae & herb \\
\hline 14 & Corydalis cashmeriana Royle. & Papaveraceae & herb \\
\hline 15 & Crawfurdia speciosa Wall. & Gentianaceae & herb \\
\hline 16 & Fragaria nubicola Lindl. & Rosaceae & herb \\
\hline 17 & Gentiana depressa D. Don & Gentianaceae & herb \\
\hline 18 & Gentiana ornata Wallich ex G. Don & Gentianaceae & herb \\
\hline 19 & Gentiana phyllocalyx C. B. Clarke & Gentianaceae & herb \\
\hline 20 & Gentiana tubiflora Wallich ex G. Don. & Gentianaceae & herb \\
\hline 21 & Geranium polyanthes Edgeworth \& J. D. Hooker & Geraniaceae & herb \\
\hline 22 & Geranium wallichianum D. Don & Geraniaceae & herb \\
\hline 23 & Geum elatum Wall. & Rosaceae & herb \\
\hline 24 & Gnaphalium hypoleucum DC. & Asteraceae & herb \\
\hline 25 & Hedychium spicatum Buch.-Ham. & Zingiberaceae & herb \\
\hline 26 & Houttuynia cordata Thunb. & Saururaceae & herb \\
\hline 27 & Iris clarkei Baker & Iridaceae & herb \\
\hline 28 & Leontopodium himalayanam DC. & Asteraceae & herb \\
\hline 29 & Leontopodium jacotianum Beauv. & Asteraceae & herb \\
\hline 30 & Lilium nepalense D. Don & Liliaceae & herb \\
\hline 31 & Lomatogonium carithiacum (Wulfen) Rchb. & Gentianaceae & herb \\
\hline 32 & Meconopsis grandis Prain & Papaveraceae & herb \\
\hline 33 & Meconopsis paniculata D. Don & Papaveraceae & herb \\
\hline 34 & Morina longifolia Wall. & Dipsacaceae & herb \\
\hline 35 & Onopordum acanthium L. & Asteraceae & herb \\
\hline 36 & Panax pseudoginseng Wall. & Araliaceae & herb \\
\hline 37 & Picrorhiza kurrooa Royle ex Benth. & Scrophulariaceae & herb \\
\hline 38 & Pieris formosa (Wallich) D. Don & Ericaceae & shrub \\
\hline 39 & Polygonatum multiflorum Allem. & Convallariaceae & herb \\
\hline 40 & Potentilla peduncularis D. Don. & Rosaceae & herb \\
\hline 41 & Pterocephalus hookeri (C. B. Clarke) Hock. & Dipsacaceae & herb \\
\hline 42 & Rheum australe D. Don & Polygonaceae & herb \\
\hline 43 & Rheum nobile Hook.f. \& Thoms. & Polygonaceae & herb \\
\hline 44 & Rubus ellipticus Smith & Rosaceae & shrub \\
\hline 45 & Rubus paniculatus Smith & Rosaceae & shrub \\
\hline 46 & Swertia chirayita (Roxb. ex Flem.) Karst. & Gentianaceae & herb \\
\hline 47 & Smilacina oleracea (Baker) Hook.f. & Liliaceae & herb \\
\hline 48 & Smilacina purpurea (Wall.) H.Hara & Liliaceae & herb \\
\hline 49 & Swertia hookeri C. B. Clarke & Gentianaceae & herb \\
\hline 50 & Tanacetum gracile Hook.f. \& Thoms. & Asteraceae & herb \\
\hline 51 & Tanacetum tibeticum Hook.f. & Asteraceae & herb \\
\hline 52 & Vaccinium nummularia Hook.f. \& Thoms. & Ericaceae & shrub \\
\hline 53 & Viscum articulatum Burm. f. & Viscaceae & shrub \\
\hline
\end{tabular}

\section{Materials and Methods}

\subsection{Sociocultural Description of the People from the Monpa Tribe}

The Monpa people are a Buddhist tribe belonging to the Mahayana (Tibetan-Lamaist) Gelukpa and Nyngmapa sect. The Monpa people are inhabitants of the western most districts of the Tawang and West Kameng regions of Arunachal Pradesh, India. Their main centers of habitation are in and around the 
administrative headquarters of Zemithang, Tawang, Dirang, and Kalaktang. Depending on the place of living and the geographical location of these centers, they are often called as Zemithang-Tawang or "Northern Monpas", Dirang or "Central Monpas", and Kalaktang or "Southern Monpas". The language used by Dirang and Kalaktang Monpa are different from that of Tawang Monpas. Dirang and Kalaktang Monpas use a dialect of Bhutanese Brokpa language, whereas Zemithang-Tawang Monpas use a dialect of Tibetan-Bhutanese Dakpa language. However, many other aspects of their life are quite similar. In Dakpa language, the name "Mon" and "Pa" signify the "Men of the Lower Country" or the inhabitants of southern regions to Tibet.

The Monpa villages are often situated on the slopes of the hills or in the valleys. A striking characteristic of the Monpa villages is the presence of a "Gompa" (Buddhist village monastery), often situated on the top of the hill and surrounded by prayer flags ("phan"), stone shrines ("mane"), and small chapels called "chorten" which are often found alongside the roads and foot-lanes. The houses are usually double or triple storeyed, and made mainly of locally sourced stone. Each house has a family chapel with a wooden, stone, or brass statue of the Lord Buddha.

The adornments and clothing are diverse and colourful. People cover their whole bodies with a variety of well-designed woolen garments. The women do the traditional spinning and weaving of the garments, as well as carpet making. The Monpa people can be recognized from a long distance owing to the attractive color of their clothing, which is a mellow strawberry red. The Monpa people love this color and dye their clothes themselves using the locally available natural dyes from diverse species of Rhododendrons and other plants. They love music and dance. Their musk-dances are very famous and attract a large number of tourists. The "Losar" or the Buddhist New Year is the most important festival celebrated among them, which is organized in February. Monpa villages could be located at a great distance by their high fluttering Buddhist prayer flags on which is printed in Tibetan script "Om Mani Pame Hung" which means "Hail to him who is born as a Jewel in a Lotus".

The Monpa people typically eat various types of locally grown vegetables, which are often cultivated by using tradtional methods [7]. Drinking yak milk, making homemade butter and dry cheese from yak milk (e.g., the famous "churpi" dry cheese), eating yak meat, pork, chicken, mutton, cultivation of multiple species of cereal and pulse through sustainable mountain agriculture based on tradtional ecological knowledges without any use of pesticides, herbicides, and chemical fertilizers are common practice [7]. Monogamy appears to be the form of marriage followed by the Tibetan Buddhist traditions. Tattooing is not typically observed among Monpa people, which is a stark contrast to the people from other tribes such as the Nishi and Adi in nearby districts. Information relating to the origin and migration of the Monpa people to their present habitat in Arunachal Pradesh is largely obscure. This is because written records on the history of Monpa people from the middle ages or beyond are very rare. Thus, it remains a matter of further anthropological and archeological research to find out the route and approximate time of their relationship with either the Tibetans or Bhutanese, or even with the people of Pan-Indian origin. When we visited Namshu village in Dirang region, the "Gaobura" or the village headman told us a folklore story about a marriage between a prince from Bhutan and a local Monpa girl from that village. The story indicates the Bhutanese influence among Dirang Monpa. The language of the Eastern Bhutan and Dirang areas are similar. Here we can quote from von Fürer-Haimendorf of Austria who was the most prominent anthropologist that ever worked with the tribes of this region [8]: "THE REGION, WHICH ADJOINS TO THE WEST OF THE MOUNTAIN KINGDOM OF BHUTAN, DIFFERS FROM THE REST OF ARUNACHAL PRADESH BOTH TOPOGRAPHICALLY AND CULTURALLY. WHEREAS, ELSEWHERE NATURE AND THE TERRAIN HAD PREVENTED THE DEVELOPMENT OF CARAVAN ROUTES SUITABLE FOR PACK ANIMALS IN THE WESTERNMOST PART OF ARUNACHAL PRADESH. HOWEVER, WHERE THE CLIMATE AND GEOGRAPHICAL CONDITION WERE FAVORABLE, THE TRADE ROUTES WERE OPENED LINKING THE TERRITORY BOTH WITH TIBET AND THE PLAINS OF ASSAM OF INDIA. HENCE CONDITIONS ARE SIMILAR TO THOSE PREVAILING IN BHUTAN AND FURTHER WEST TO SIKKIM AND NEPAL. ALONG WITH THESE TRANS-HIMALAYAN TRADE ROUTES, TIBETAN CULTURAL ELEMENTS 


\subsection{Study Area}

The study area is located in the extreme north of the north-western Arunachal Pradesh. The areas of investigations are situated at the Lumla-Zemithang administrative circle of the Tawang district of Arunachal Pradesh (Figure 1). This region is situated along the bank of the river Namshyang Chu that flows through the area. The name, exact locations, and altitude of the three villages where the study took place are as follows: (1) village Kublaitang $\left(27^{\circ} 37^{\prime} 070^{\prime \prime} \mathrm{N}, 91^{\circ} 41^{\prime} 618^{\prime \prime}\right.$ E, elevation $\left.2224 \mathrm{~m}\right)$; (2) village Shakti $\left(27^{\circ} 36^{\prime} 736^{\prime \prime} \mathrm{N}, 91^{\circ} 42^{\prime} 970^{\prime \prime} \mathrm{E}\right.$, elevation $\left.2020 \mathrm{~m}\right)$; and (3) village Lumpho $\left(27^{\circ} 43^{\prime} 140^{\prime \prime} \mathrm{N}\right.$, $091^{\circ} 43^{\prime} 069^{\prime \prime} \mathrm{E}$, elevation $2550 \mathrm{~m}$ ). The research areas fall under the middle Himalayan range of the Eastern Himalayas. The soil on the hills is moderately deep and moist, fertile loamy layer stained with humus. At places, shallow soils are not uncommon with underlying boulders and rocks. The subsoil at lower elevations consists of mostly boulders and pebbles superimposed by a layer of a sandy loam of various depths with layers of humus overtop. The relative humidity of this area varies from $30 \%$ to $80 \%$. Southern aspects at low altitude areas are more humid than any other places in the region. The annual temperature in this area varies from -10 degrees Celsius to +15 degrees Celsius. The area typically receives 1500-1800 mm rainfall every year. The dry months are December, January, and February. The pre-monsoon rainfall starts from the end of the March. Highest rainfall is observed in June, July, and August [9]. The forest type of the research area is the Northeastern Himalayan subalpine mixed conifer forests. The top canopy of the forest consists of Abies densa, Juniperus wallichiana, Illicium griffithi, Pinus wallichiana, Quercus spp., and Cupressus torulosa. The secondary canopy layer mainly consists of Rhododendron spp., Betula utilis, Pyrus aucuparia, and Salix wallichiana. The trees of the forest ground storey are dominated by Juniperus recurva, Cassiope fastigiata, and Rhododendron spp. [10].

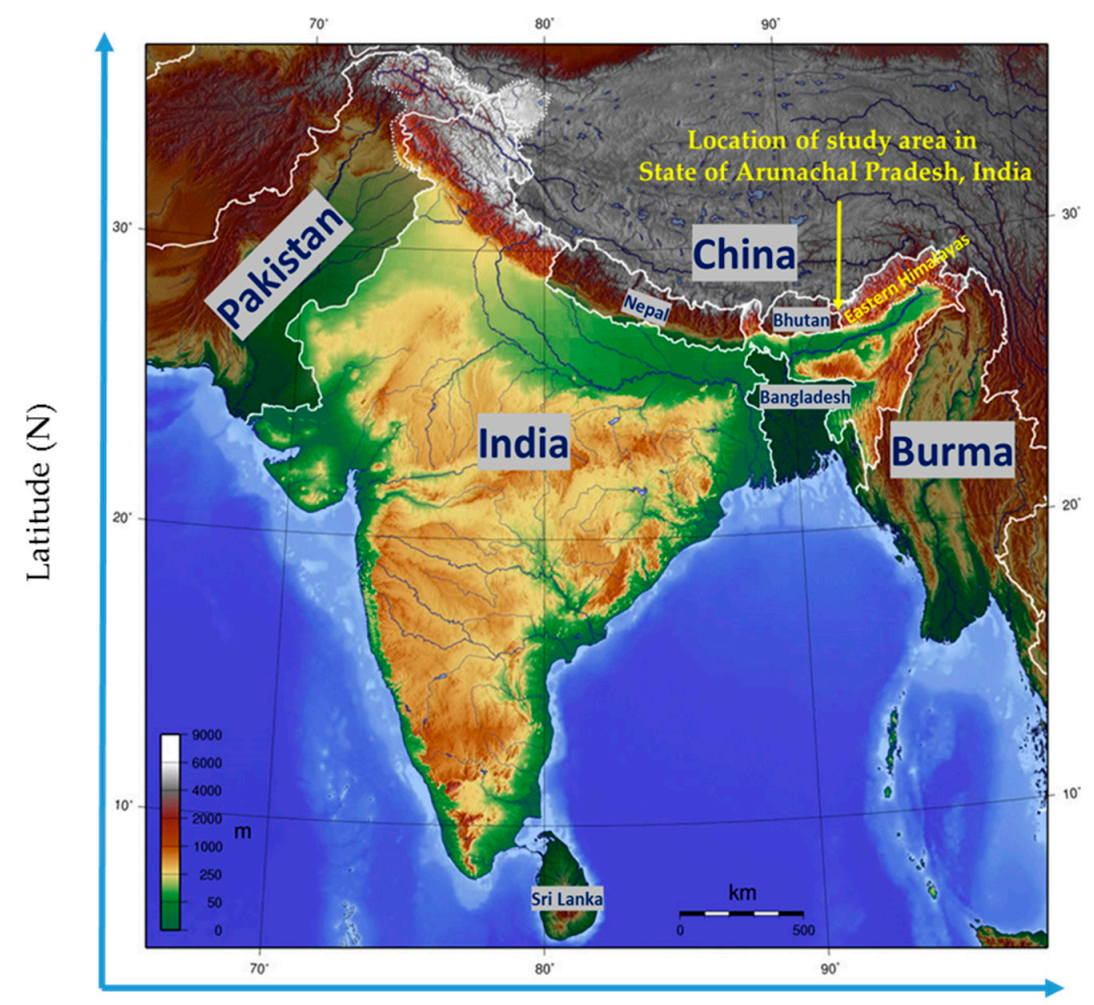

Longitude (E)

Figure 1. Location of the study area at the Zemithang region in the state of Arunachal Pradesh, India pointed by the yellow arrow (map not to scale). 


\subsection{Field Surveys}

Field surveys were carried at the three sample villages of the Zemithang region of Tawang district. The research was carried out in three stages. In the first stage, ethnobotanical data were collected from the research area. At the second stage, ethnopharmacological information was collected from the same research area. The herbariums of the collected plant specimens were prepared and verified at the third stage of the research at the Forest Research Institute of Dehradun, India. The field identifications of the plants were mostly done by using field guide with colored photographs of the plants by Polunin and Stainton [11]. Some unidentified and partially identified plants from the field were brought to the specialists at the Forest Research Institute of Dehradun, India for full identification. The participatory transect walk, interview, and discussions with traditional healers were used for ethnobotanical data collection. The total number of participatory transects established were three for every village, resulting in a total of nine across all three villages. The length of each transect was $2 \mathrm{~km}$ from the center of the village to three different outward directions, depending on aspects of the village. We used three different groups for the transect walks. These groups were common village people including men and women, hunters, and traditional healers. Two walks with every group with different people were conducted. As such, the total number of transect walks per village was six, thereby totaling 18 transect walks across all three villages. This type of data collection design was followed for the robustness of ethnobotanical information. Apart from this technique for collecting plant specimens with ethnobotanical values, we used a structured questionnaire for interviews and group discussions regarding the ethnopharmacological techniques of medicine preparation for the collected plants. The people who participated in transect walks were not selected for questionnaire surveys in order to avoid repetition and establish a more general idea among larger population groups. The participatory transect walks were mostly carried out in spring and summer when a large flush of herbaceous plants grow in the forest, pasturelands, and meadows after the melting of winter snow. At the second stage of the research, ethnopharmacological information was collected from the high ranked monks and traditional healers who prepare medicine from plants for the healing of the tribal people. In each village, we selected at least three independent healers or monks for this purpose. After gathering the information, we performed a qualitative assessment for reaching a consensus among the respondents and rejected the conflicting responses. The basic information that was collected from these monks and traditional healers were regarding (1) the plants needed to make medicine; (2) the use of plant parts; (3) the different ratios of plant use; (4) the techniques of preparation; (5) the doses and prescription to the patients; and (6) the medicinal uses. The third stage of the research was carried out at the Resource Survey and Management Division of the Forest Research Institute, Dehradun, India. Taxonomical classification was performed with the help of the Botany Division of the Forest Research Institute, and identified plant specimens were confirmed by using the herbaria of the same division for comparison purposes. The specimens with detailed taxonomic information, name of collectors, and place and date of collections were finally deposited to The Course Coordinator of Postgraduate Programs, Forest Research Institute University (Dehra Dun, India) for future references. We had received permission from the local forest authorities in addition to having obtained consents from the traditional healers before doing this survey.

\section{Discussion}

The list of plant species and utilization of plant parts for different diseases documented in this study support a recent study carried out by Namsa et al. (2011) on the southern or Kalaktang Monpas [6]. The list we provided for the medicinal plants is not completely new to ethnobotanists, as it was already listed in old research works on medicinal plants of the Himalayas (see [12-14]). This proves that the plants we listed are already confirmed as "medicinal plants" by past researchers from the other parts of the Himalayas. However, the detailed ethnopharmacological descriptions or traditional ways of preparation for the herbal drugs and medicines were rarely documented. Due to this reason, a search with the terms "ethnopharmacology * Himalayas" yielded only three articles on 20 February 2017 in 
the ISI Web of Knowledge. For example, Gangwar et al. [15] worked on ethnopharmacological uses of Mallotus philippinensis Muell. Arg, and Stobdan et al. [16] did a similar work on Hippophae rhamnoides L. We found only one article, a study by Abbasi et al. [17], that was similar to our study and described ethnopharmacological knowledges of medicine preparation from a Himalayan region of the Pakistan Himalayas. Therefore, we emphasize that this is the first documented study on ethnopharmacology of a tribe from Arunachal Pradesh. We assume that in most cases modern pharmacologists and researchers start chemical assessments of the medicinal plants without giving much attention to the traditional ways of drug preparation by the tribal communities. This could be the reason behind the high number of studies on ethnobotany of medicinal plants from the Himalayas, but the comparatively minimal number of studies on ethnopharmacology. In South India, the Kani tribe uses similar approach for traditional medicine making [5], which supports the notion that tribal healers do use certain systematic techniques for drug preparation. The ethnopharmacological knowledge of traditional healers are generally transferred orally to the next generation, thus, making the knowledge vulnerable to being forgotten or lost.

In this context, we would like to provide a few examples of past pharmacological studies that had reported similar utilization of some medicinal plants listed in this study. Ghildiyal et al. (2012) showed that ethanolic extracts from Hedychium spicatum can inhibit respiratory as well as gastrointestinal disorders in rats and guinea pigs [18]. We showed in this study that the ethnomedicine Blenga prepared from the same plant was used for the treatments of dysentery and chest pain. In 2007, Nazir et al. extracted a drug called "Bergenin" from the species Bergenia stracheyi and proved that this drug can be used to treat arthritis in mice [19]. Interestingly, we found that an ethnomedicine named as Bragen (prepared from Bergenia stracheyi as well) was also used for the treatment of arthritis. Recently in 2014, Kumar et al. reported that the extracts of Houttuynia cordata can be used for the healing of hemorrhoids, and this species is frequently used in tradtional Tibetan and Chinese medicines [20]. We found that the ethnomedicine Maraptang prepared from Houttuynia cordata were also used by the tradtional Monpa healers for the treatment of piles which is a type of hemorrhoid. These examples mentioned above showed that the tradtional ethnomedicines used by the healers of Zemithang Monpa may have some potential to cure or manage some diseases. However, detailed pharmacological studies are needed to evaluate the potential of these medicines. A study by Witt et al. (2009) in Sikkim and Eastern Nepal (also part of the Eastern Himalayas) comprehensively listed 138 species of plants from tropical to alpine regions of the Himalayas used specifically in Tibetan medicine [21]. The majority of the species listed in our study were also reported by Witt et al., but detailed descriptions of the preparations for the ethnomedicines were not provided.

The results of this study should be interpreted very cautiously. The traditional ethnopharmacological knowledge of the Zemithang-Monpa tribe presented here for some diseases must not be treated as a general prescription under any circumstances, as scientific trials have not been undertaken nor the "traditional ethnomedicines" have ever been certified by any governmental authority such as the Central Drugs Standard Control Organization of India. There is also a high probability that the descriptions presented here may not be the same throughout the study region. Nevertheless, our main goal was not to certify or validate traditional medicines, but rather to document the uses and preparation of traditional medicines used by tribal people. The field method applied for data collection (i.e., participatory transect walk) also had some limitations. This method was helpful in remote regions where time and logistics are always a constraint of field work. Nevertheless, future research should establish more sample plots and cover larger regions in order to list more medicinal plants.

\section{Conclusions}

We have documented for the first time the vernacular names combined with ethnopharmacological preparations of ethnomedicines among Monpa tribes from the Zemithang region of Arunachal Pradesh, India. Past studies on ethnobotany in the Arunachal Pradesh, Eastern Himalayas, had listed uses 
of medicinal plants, however, we found that traditional healers use diverse species and plant parts in specific proportions for drug preparations. Our study illustrates the diversity of medicinal drug preparations and traditional knowledge that has passed through generation after generation of Monpa people. The ethnopharmacological documentation presented in this study should motivate researchers to carry out further scientific work on pharmacology, bioprospecting, and the cultivation of medicinal plants for the socioeconomic development in the region. Under ongoing warming of the Himalayas and mass migration of people from the mountain areas to cities, our study also highlights the need to document the traditional knowledge regarding the use of local flora and to develop strategies to conserve them before the traditional knowledges are lost or forgotten.

Acknowledgments: We sincerely thank the Divisional Forest Officers (DFOs) of Tawang Social Forestry Division and West Kameng Forest Division (Suneesh Buxy, M. Sambhu and Adukparon of Indian Forest Service) and R. C. Das (the Range Forest Officer, Lumla Forest Range, Arunachal Pradesh State Forest Service) for giving us permission and providing logistical support to do the field work. Without their support, this study could not have been done in this remote part of India. We thank Prema Khandu (village Lumpho) and Norbu (village Namshu) for all the supports provided during field data collection, and for organizing and participating in long field expeditions. We will never forget the support from Haridasan and Rao (State Forest Research Institute of Arunachal Pradesh, Itanagar), Saroj K. Barik (North Eastern Hill University, Shillong), and Mohammed Latif Khan (Northeastern Regional Institute of Science and Technology, Itanagar) in the identification of herbarium samples. We also acknowledge the cooperation provided by the Pijush K. Datta of WWF-India and Bibhab Talukdar of ATREE-Northeast Program and the IUCN-India during this research work. The article processing charge was funded by the open access publication fund of the Albert-Ludwigs-University of Freiburg.

Author Contributions: Tamalika Chakraborty and Somidh Saha conducted the field work, wrote the paper, and equally contributed to this work. Narendra Singh Bisht provided motivation, guidance, and supervision to carry out this research and acted as mentor for the graduate research works of Tamalika Chakraborty and Somidh Saha.

Conflicts of Interest: The authors declare no conflict of interest.

\section{References}

1. Borges, R.M. The frontiers of India's biological diversity. Biotropica 2005, 37, A1-A3.

2. Haridasan, K.; Bhuyan, L.R.; Deori, M.L. Wild edible plants of Arunachal Pradesh. Arunachal For. News 1990, 18, 1-8.

3. Adak, D.K. A morphometric study of the Thingbu-pa and population comparison with neighbouring Monpa tribes of Arunachal Pradesh, India. Anthropologischer Anzeiger Bericht uber die Biologisch-Anthropologische Literatur 2001, 59, 365-375. [PubMed]

4. Sharma, P.P.; Mujundar, A.M. Traditional knowledge on plants from Toranmal Plateau of Maharastra. Indian J. Tradit. Knowl. 2003, 2, 292-296.

5. Ayyanar, M.; Ignacimuthu, S. Traditional knowledge of kani tribals in Kouthalai of Tirunelveli hills, Tamil Nadu, India. J. Ethnopharmacol. 2005, 102, 246-255. [CrossRef] [PubMed]

6. Namsa, N.D.; Mandal, M.; Tangjang, S.; Mandal, S.C. Ethnobotany of the Monpa ethnic group at Arunachal Pradesh, India. J. Ethnobiol. Ethnomed. 2011, 7, 31. [CrossRef] [PubMed]

7. Saha, S.; Bisht, N.S. Role of traditional ecological knowledge in natural resource management among Monpas of north-western Arunachal Pradesh. Indian For. 2007, 133, 155-164.

8. Von Fürer-Haimendorf, C. Tribes of India: The Struggle for Survival; Oxford University Press: Delhi, India, 1982.

9. State Government of Arunachal Pradesh. Working Plan: Tawang Social Forestry Division; Arunachal Forest Department: Tawang, India, 2001.

10. Champion, S.H.G.; Seth, S.K. A Revised Survey of the Forest Types of India; Government of India: New Delhi, India, 1968.

11. Polunin, O.; Stainton, A. Flowers of the Himalayas; Oxford University Press: Delhi, India, 1997.

12. Haridasan, K.; Shukla, G.P.; Beniwal, B.S. Medicinal plants of Arunachal Pradesh. SFRI Inf. Bull. 1995, 5, 32.

13. Kala, C.P. Medicinal Plants of Indian Trans-Himalaya: Focus on Tibetan Use of Medicinal Resources; Bishen Singh Mahendra Pal Singh: Dehra Dun, India, 2003.

14. Kala, C.P. Status and conservation of rare and endangered medicinal plants in the Indian trans-Himalaya. Biol. Conserv. 2000, 93, 371-379. [CrossRef] 
15. Gangwar, M.; Goel, R.K.; Nath, G. Mallotus philippinensis Muell. Arg (Euphorbiaceae): Ethnopharmacology and phytochemistry review. BioMed Res. Int. 2014, 2014, 213973. [CrossRef] [PubMed]

16. Stobdan, T.; Targais, K.; Lamo, D.; Srivastava, R.B. Judicious use of natural resources: A case study of traditional uses of seabuckthorn (Hippophae rhamnoides L.) in trans-Himalayan Ladakh, India. Natl. Acad. Sci. Lett. 2013, 36, 609-613. [CrossRef]

17. Abbasi, A.M.; Khan, M.A.; Zafar, M. Ethno-medicinal assessment of some selected wild edible fruits and vegetables of Lesser-Himalayas, Pakistan. Pak. J. Bot. 2013, 45, 215-222.

18. Ghildiyal, S.; Gautam, M.K.; Joshi, V.K.; Goel, R.K. Pharmacological evaluation of extracts of Hedychium spicatum (Ham-ex-Smith) rhizome. Anc. Sci. Life 2012, 31, 117-122.

19. Nazir, N.; Koul, S.; Qurishi, M.A.; Taneja, S.C.; Ahmad, S.F.; Bani, S.; Qazi, G.N. Immunomodulatory effect of bergenin and norbergenin against adjuvant-induced arthritis-A flow cytometric study. J. Ethnopharmacol. 2007, 112, 401-405. [CrossRef] [PubMed]

20. Kumar, M.; Prasad, S.K.; Hemalatha, S. A current update on the phytopharmacological aspects of Houttuynia cordata Thunb. Pharmacogn. Rev. 2014, 8, 22-35. [PubMed]

21. Witt, C.M.; Berling, N.E.; Rinpoche, N.T.; Cuomo, M.; Willich, S.N. Evaluation of medicinal plants as part of Tibetan medicine prospective observational study in Sikkim and Nepal. J. Altern. Complement. Med. 2009, 15, 59-65. [CrossRef]

(C) 2017 by the authors. Licensee MDPI, Basel, Switzerland. This article is an open access article distributed under the terms and conditions of the Creative Commons Attribution (CC BY) license (http:/ / creativecommons.org/licenses/by/4.0/). 